\title{
The Way Forward: The Power of Diversity
}

\author{
Ako Muto and Yoichi Mine
}

\subsection{INTRODUCTION}

The case studies in this volume have dug deep into the process of localization of the human security norm-complex in the 11 countries of East Asia. As indicated in Chap. 1, there are three major characteristics that stand out in these case studies. First, the surveys uncover a wide variety of issues that are locally considered critical and pervasive threats to human security; political conflict and repression are included in this list, but we have found that the range of perceived human security threats is much wider than that. Second, human security consists of clusters of norms, and each component (freedom from fear and want, freedom to live in dignity, protection and empowerment) has been well understood, accepted, and put into practice in East Asian countries. Thus, the parts are already there, but another push seems necessary to elevate human security to a full-fledged international norm.

A. Muto $(\square)$

Research Institute, Japan International Cooperation Agency (JICA), Tokyo, Japan

e-mail: Muto.Ako@jica.go.jp

Y. Mine

Graduate School of Global Studies, Doshisha University, Kyoto, Japan e-mail: ymine@mail.doshisha.ac.jp

(C) The Author(s) 2019

Y. Mine et al. (eds.), Human Security Norms in East Asia, Security, Development and Human Rights in East Asia, https://doi.org/10.1007/978-3-319-97247-3_14 
Third, in many countries, the national government is expected to assume the role of guarantor of human security. As meticulously discussed in the comparative analysis in Chap. 13, this protective role of the state is generally appreciated by scholars and practitioners of human security in the region. In fact, wedding the idea of human security to the expected functions of national governments may be the most salient feature of the localization of the human security norm in East Asia. The same chapter also indicates that there is a shared perception that a host of serious human insecurities is caused by the process of rapid economic development in the region. It is imperative for us to pay closer attention to the quality of growth especially because the East Asian region is still a major engine of growth for the world economy.

Based on the findings in regionwide surveys and insightful comparison, this final chapter, a slightly long epilogue to the book, attempts to provide some food for thought not only for scholars but also for practitioners of human security and development in East Asia and worldwide. While this book presents constructivist perspectives such as norm dynamics and security communities, its core message is meant to reach beyond the scholars of international relations (IR), as it is part of an endeavor to find the conditions to create a "community of practice" (Wenger 1998; Adler 2005) of human security in the East Asian region. Such a community will provide the normative and epistemic grounds for concerted action to realize human security.

In 2013, the United Nation Secretary General (UNSG) released a document on global human security practice, which is presented according to the three levels of governance: national (and sub-national), regional, and international (UNSG 2013). The discussion in the rest of this chapter is presented according to these three dimensions. While the UNSG document was based on questionnaire surveys covering the broad UN member states, the present book complements it by advancing a focused inquiry targeting the East Asian region in more depth. At the end of this book, we will return to the definition of human security and discuss why human security eventually had to be separated from its "sibling," the responsibility to protect (R2P).

\subsection{Empowerment and Capacity Development: The National Dimension}

Human security is practiced by combining top-down protection with bottom-up empowerment. Although people may empower themselves without waiting for intervention from domestic authorities or international 
donors, our comparative analysis (Chap. 13) argues that in East Asia, governments are widely expected to extend parental care and lead people to the right path; we may call this "guided empowerment." Some case studies in this volume review this function in a positive light, while others envision the promotion of civil society that will act as a democratic counterbalance to authoritarian governments. Although empowering people while protecting them appears to be a contradiction, those holding power may practice both in the passage of time in a similar way to the process in which parents protect and bring up children: the young will eventually take control of their own life and may challenge, and even protect, their parents. The notion of paternalism invites mixed, sometimes emotional reactions. ${ }^{1}$

By definition, empowerment "aims at developing the capabilities of individuals and communities to make informed choices and to act on their own behalf. Empowering people not only enables them to develop their full potential, but it also allows them to find ways and to participate in solutions to ensure human security for themselves and others" (UNHSU $2009,7)$. In short, empowered people will possess enhanced levels of problem-solving capacity. If the capacity of individuals and communities to make informed choices is weak, the government may have to set up institutions and provide resources to assist them in making their own decisions. Then, if the capacity of the government to empower people is weak, deficiencies could be filled by means of international aid. The practice of empowerment and that of capacity development are thus closely related.

The concept of capacity development gained currency among international donors in the early 2000s (Fukuda-Parr et al. 2002). Under the presidency of Sadako Ogata, the Japan International Cooperation Agency (JICA) took up the task of operationalizing capacity development at the same time as it absorbed the idea of human security. In its capacity assessment handbook, JICA distinguished three elements of capacity at each of the individual, organizational, and societal levels: the first element is the "technical capacity," which takes the form of particular skills and knowledge (including tacit knowledge); the second is the "core capacity," which refers to leadership capabilities and motivation to utilize the technical capacity; and the third is the "enabling environment," which makes target organizations produce results with an increased capacity. JICA emphasizes the significance of nurturing the core capacity at the organizational level, which is supposed to be the leverage point in many cases (JICA 2008, 14-22). International donors including the World Bank, the Asian Development Bank, the United Nations Development Programme 
(UNDP), the European Commission, the Department for International Development (DfID), and Deutsche Gesellschaft für Internationale Zusammenarbeit (German Society for International Cooperation-GIZ) $\mathrm{GmbH}$ have developed their principles and programs with regard to capacity development.

The initiative to develop people's problem-solving capacity may be taken by national governments or international donors. The process of empowerment can also proceed in the private economy or intimate spheres independently of the authorities. In any case, if citizens are sufficiently empowered, they may want to change their environments and courses of life from bottom up or begin to resolve local problems collectively by themselves. Empowered individuals may also demand more of government authorities, and if the delivery is short of their expectations and perceived as unjust, they may want to "punish" the national authorities through democratic mechanisms. Otherwise, the same citizens may want to sacrifice themselves voluntarily as "unknown soldiers" to preserve their own imagined (national) community in face of threats posed from the outside (B. Anderson 1983). In East Asia, the time of "oriental despotism," in which obedient rural subjects were mobilized from top down for public works (Wittfogel 1957) is definitely over, as people now think and act on their own. Thus, the path of East Asia's further empowerment and democratization is not predetermined.

The concept of freedom to live in dignity is related to the cultural aspect of human life. In the process of post-war decolonization, people in the newly independent nations called for the restoration of national dignity. The prevalence of dignity in the culture of the UN is closely related to the expansion of the territories in which people are regarded as members of legitimate sovereign nations to which the sacred right of selfdetermination has been conferred. In Northeast Asia, the concept of national dignity possessed by all formally sovereign and equal nations came into existence with the rise of modern nationalism in the twentieth century, resulting in entangled discourses of equality and hierarchy (Fitzgerald 2006). From the human security perspective, national dignity and individual dignity are both highly esteemed: human security requires international donors to pay respect to national self-determination and obliges national governments to respect the intrinsic value of individual citizens. The challenge is thus dual. The principle of ownership has become part and parcel of human security practice by incorporating the concept of dignity into the norm-complex. 


\subsection{Diversity of the East Asian Nations: The Regional Dimension}

The chapters of this volume have provided a comprehensive list of nontraditional and traditional threats: natural disasters (earthquakes and typhoons/cyclones), environmental pollution, climate change, epidemics, violent conflict, political repression, religious tensions, human trafficking, minority issues, unemployment, conditions of migrants, food crises, lingering poverty, and so on. In a given country, people are exposed to a certain set of threats due to their geographic location, the state of economic development, and other unique factors. The land-locked country of Laos will never experience a tsunami, for example.

The East Asian nations are extremely diverse. In terms of territory and population size, one may hesitate to lump China and Singapore together in the same category of nation states. In this region, presidential or parliamentary republics, constitutional monarchies, and communist regimes coexist side by side. Countries like Indonesia, Malaysia, and China are rich in natural resources, while Singapore, Thailand, South Korea, and Japan are less endowed. Before anthropologists discovered the notion of cultural relativism, East Asians were long accustomed to this way of thinking; the region has accommodated diverse indigenous and exogenous cultures and religions like Confucianism, Buddhism, Christianity, Islam as well as various sorts of animism. Hundreds of languages are spoken in Indonesia while basically one language is used in a country like Japan. However, such diversity has never hindered the economic development of East Asia. More than two decades after the publication of the East Asian Miracle, which attributed the rapid economic growth of the East Asian tigers to good education and appropriate industrial policies (World Bank 1993), most national economies continue growing with the strong backing of relatively efficient bureaucracies and capable administrations. It is noteworthy that the capacity development of government institutions by means of knowledge transfer has always been an important component of Japan's development assistance.

In the meantime, China has become the second largest economy in the world, and South Korea is now a member of the Organisation for Economic Co-operation and Development-Development Assistance Committee (OECD-DAC). Despite the miraculous economic successes and deepening value chains in the region, a common security arrangement has not 
taken shape in East Asia, where sovereign nations still compete against each other openly. Since the 1950s, the North Atlantic world have nurtured layers of regional organizations, called "security communities" by Karl Deutsch and his colleagues, in which all community members expect that disputes among the states will be settled in peaceful, non-military ways (Deutsch et al. 1957). Given that the emergence of such security communities followed the deepening of economic and cultural ties rather than the formation of military alliances (Ruggie 1996, 85), the time for a security community in East Asia where we witness a remarkable degree of economic integration may already be ripe. However, a political community that would share sovereignty is not preferred in this region, and as shown in the case study chapters and discussed later in this chapter, most are also skeptical about the R2P style intervention within the region. Nevertheless, in East Asia, it may not be difficult to reach a consensus to organize multiple cooperative platforms ${ }^{2}$ to address particular human security challenges, thereby building a pluralistic "human security community" in which member states collaborate while retaining national sovereignty (Hernandez et al. 2018).

Regarding the prospect of the regional cooperation for human security, the Association of Southeast Asian Nations (ASEAN) stays one step ahead. On top of the accelerated effort to consolidate the ASEAN community in its political-security, economic and socio-cultural aspects, ASEAN is taking concerted action to address non-traditional security issues (Acharya 2014; Caballero-Anthony 2016). Among the five world regions (Asia, Africa, Americas, Europe, and Oceania), from 2006 to 2015, 40 percent of natural disasters took place in Asia, and 51 percent of the related total casualties were people who lived in the region (IFRC 2016, 232-3). As Southeast Asia is a specifically disaster-prone area, ASEAN has advanced regional cooperation in disaster management in the framework of the ASEAN Agreement on Disaster Management and Emergency Response (AADMER), which is "a legally-binding, regional multi-hazard and policy framework for cooperation, coordination, technical assistance, and resource mobilization" (UNOCHA-ROAP 2013). While Japan contributes to this initiative, ASEAN also succeeded in collaborating with China, with the support of the World Health Organization (WHO), when the Severe Acute Respiratory Syndrome (SARS) broke out. In responding to the SARS crisis, the ASEAN Plus Three (China, Japan, and South Korea) framework was utilized (Acharya 2014, 217-8). 
Depending on the choice of criteria, East Asian states can be classified into several groups with asymmetric power configurations. It is widely known that hierarchical regimes with centralized power structures historically developed in the plain regions of the Eurasian continent, while flexible, amorphous, and network-based polities prevailed largely in mountain areas as well as islands and archipelagoes in the Pacific (see, e.g., Geertz 1980; Scott 2009). Today, we face an intriguing paradox: while traditionally centripetal governments in China, Japan, and South Korea develop strained relationships among themselves, relatively centrifugal governments in Southeast Asia have steadily and tenaciously advanced the community formation of ASEAN. The future of a human security community in East Asia hinges upon whether equal partnership can be matured between these two asymmetric powers, namely, between ASEAN and the "Plus Three." A positive aspect is that, despite the political rivalry, a culture of mutual respect is gradually fostered, and there are active collaborative networks in civil society, business, and academia across the region. If East Asia can sustain growth while assuming the responsibility to address global human security issues, the region may give rise to an Asian version of the OECD in the future.

\subsection{The Sustainable Development Goals (SDGs) and Human Security: The Global Dimension}

It is very clear from the case studies that East Asian experts of human security share a view that multilateral assistance is much preferable to unilateral intervention. Presently, the most important multilateral framework to solve global problems is the SDGs. The "2030 Agenda for Sustainable Development" was adopted at the UN Summit in September 2015, and the 17 SDGs of the Agenda were released in January 2016. The SDGs build on the success of the Millennium Development Goals (MDGs), but "the new Goals are unique in that they call for action by all countries-poor, rich, and middle-income - to promote prosperity while protecting the planet." Moreover, "while the SDGs are not legally binding, governments are expected to take ownership and establish national frameworks for achievement of the 17 Goals." ${ }^{3}$ East Asian countries have already started to elaborate their own programs to meet these goals by 2030, and their efforts will be accelerated as the target year draws nearer. 
There are two critical points that link the human security perspective with the practice to realize the SDGs. The first relates to the role of the government. Although the SDGs seek a strong alliance with the private sector and civil society, Article 41 of Agenda 2030 notes that the state can play a significant role: "We recognize that each country has primary responsibility for its own economic and social development." Second, the SDGs appear to pay less attention to risks and resilience that feature the discourses of human security, and this gap is expected to open a new field of complementary action. As Fig. 14 .1 shows, the process of human development cannot be a linear progress. If development is the process of expanding people's freedom, human security aims at removing sources of people's unfreedom. Calamities such as wars, armed conflicts, outbreaks of infectious diseases, and natural and human-made disasters pounce upon a wide swath of people at a time. The focus on these "downside risks" is part of the theoretical underpinnings of the human security concept (Sen 2014). In the risk-prone societies of our time, even though both haves and have-nots are equally exposed to cross-border threats such as air pollution, multiple risks compel the most vulnerable people to suffer most, intensifying their insecurities (Beck 1992). These are the people who need to be protected and empowered most urgently.

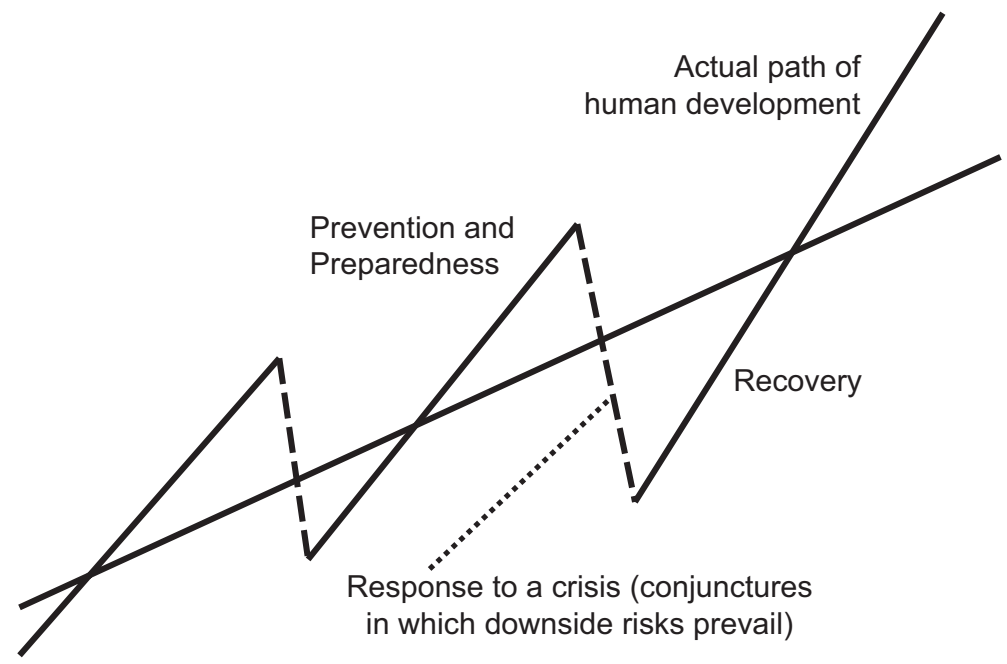

Fig. 14.1 Human security and development. Adapted from Mine (2007, p. 72) 
Let us use some illustrative examples. When violent conflict breaks out, those civilians who do not possess resources to evacuate or emigrate become easy targets of warring parties. In refugee camps, strong men often monopolize distributed foods and deprive women, children, and the weak of their food entitlements. The socially excluded persons living with human immunodeficiency virus infection and acquired immune deficiency syndrome (HIV/AIDS) may not have access to effective treatment even though the government provides such a service. In debt-laden households, young voiceless children fall prey to human trafficking. People who have no choice but to live in a wetland delta have their houses swept away by deluges caused by global climate change. People who cannot but choose the cheapest foods are exposed to the risks of dangerous food additives. And finally, those who have decided to sacrifice their lives for others may be tortured and "disappear" when the government turns against its own citizens. These are all human security issues, and simultaneously, it is these sufferings that must be addressed by the SDGs.

Downside risks, or critical and pervasive threats to human security, may hinder sustainable human development and exert grave impact on specific groups of vulnerable people. Traditionally, the UNSG regarded inter-state wars as the central threats to peace and security of the world, but the UN has already begun to discuss ways to address global risks other than classic wars, such as economic and social threats (including poverty, diseases, and environmental degradation), violent conflict within the nation, new weapons, terrorism, and transnational organized crime (UN 2004). While the SDGs aim to reach a set of prescribed goals, human security strives to deal with the obstacles in the way of these shared goals and examines who are affected most adversely by those obstacles. Amartya Sen proposed a methodology of disaggregation in his Poverty and Famine, a classic analysis of famine crises in South Asia and Africa (Sen 1981): even when the total food supply seems to be sufficient in the nationally aggregated data, specific groups (including landless people) can starve to death, especially when they are wracked by ferocious market forces. Focusing attention on such variables as gender, generation, occupation, and geographic location, we should be able to clearly understand the differential vulnerability of particular communities and individuals to human security threats. ${ }^{4}$

In East Asia, people often refer to natural disasters, infectious diseases, and political conflict as typical human security issues. In the list of the SDGs, these issues are featured in Goal 11 (Make cities and human settle- 
ments inclusive, safe, resilient, and sustainable), Goal 3 (Ensure healthy lives and promote well-being for all at all ages), and Goal 16 (Promote peaceful and inclusive societies for sustainable development, provide access to justice for all and build effective, accountable and inclusive institutions at all levels). We can also check how many times the keywords of human security such as want, fear, dignity, protection, and empowerment appear in the text of the SDGs; for example, empowerment is explicitly used in Goal 5 (Achieve gender equality and empower all women and girls). However, these exercises to find thematic overlaps may be misleading, as an international norm is not just a set of issues and keywords but a certain collective expectation for appropriate action. The idea and practice of human security have unique potential to contribute to the overall achievement of the SDGs through its focus on risks, vulnerability, and an ethical imperative of "no one left behind" as a global concern.

\subsection{Human Security and the Responsibility to Protect}

Finally, let us revisit the definition of the human security norm-complex. In 2012, the United Nations General Assembly (UNGA) adopted a resolution on the definition of human security (UNGA 2012; see also Chap. 1 of this volume). According to this document, a common understanding of human security includes: "The right of people to live in freedom and dignity, free from poverty and despair. All individuals, in particular the vulnerable people, are entitled to freedom from fear and freedom from want, with an equal opportunity to enjoy all their rights and fully develop their human potential." In this text, freedom is defined in terms of the duality of peace (absence of fear) and development (elimination of want), and juxtaposed with the right to live in dignity, with special emphasis given to the rights of vulnerable people. Development of "human potential" resonates with the idea of human development, which was originally defined as the process of enlarging people's choices. The resolution fleshes out the concept further in subsequent paragraphs that begin with: "(b) Human security calls for people-centred, comprehensive, context-specific and prevention-oriented responses that strengthen the protection and empowerment of all people and all communities."

As discussed in Chap. 1, human security is a norm-complex that consists of a cluster of related norms, and this hybridity allows for different interpretations of human security. This is one of the reasons why the title 
of this book is Human Security Norms in the plural, rather than the human security norm in the singular (the other reason lies in a variety of interpretations of the concept in different countries in East Asia). Since the introduction of the concept to the UN discourse around 1994, human security has been regarded by some as a sort of "patchwork" of norms. Human security was criticized by Paris (2001) and others as a "vague" and "useless" concept in a series of debates that largely took place in the North Atlantic region. ${ }^{5}$ The definition of human security in the 2012 UNGA resolution was agreed upon as a compromise among diplomats from the UN member states with starkly different backgrounds. As such, the latest definition also appears to remain elusive.

In fact, however, the message of human security redefined in the 2012 UNGA resolution seems powerfully comprehensive and far from ambiguous. The purport becomes clear when we contrast human security with its adversarial "sibling," the R2P, which was originally born as a sharp-edged, narrow interpretation of the human security concept (ICISS 2001). The UNGA resolution redefined human security as an opposite of the R2P approach: "(d) The notion of human security is distinct from the responsibility to protect and its implementation." It also specifies the role of the state and international community engaged in assistance in case of humanitarian crises: "(e) Human security does not entail the threat or the use of force or coercive measures. Human security does not replace State security." In addition, "(f) Human security is based on national ownership (...)," and "(g) Governments retain the primary role and responsibility for ensuring the survival, livelihood and dignity of their citizens. The role of the international community is to complement and provide the necessary support to Governments, upon their request, to strengthen their capacity to respond to current and emerging threats. Human security requires greater collaboration and partnership (...)."

When applied to a humanitarian emergency, the R2P approach is supposed to simplify the problem, react to the crisis, mobilize the military, enter the sovereign territory, and protect citizens. In contrast, the priority of the human security approach in the UN is now understood to contextualize the problem, prevent the crisis, coordinate activities of various actors, respect national sovereignty, and empower citizens from the bottom up. In every respect, human security as defined in the 2012 resolution is the antithesis of the conventional interpretation of the R2P. ${ }^{6}$ The action to address humanitarian crises has been discussed much in the analogy of 
medical practice such as "do no harm," a phrase in the Hippocratic Oath (M.B. Anderson 1999). While the R2P is like a "surgical" or "invasive" therapy targeting troubled society, human security seems closer to an "internal" or "oriental" medicine designed to promote the resilience of an organism. When multilateralism flourishes, the ideas of human security and the R2P, as well as their confrontation, complementarity and entanglements, attract keen public attention. However, when the enthusiasm for multilateral thinking recedes, it appears that both ideas tend to be sidelined.

Still, it is noteworthy that most respondents in our case studies did not confuse human security with the R2P, indicating that the comprehensive approach to human security is taking root in the region. After having witnessed how the R2P was applied and not applied since the Libyan case in 2011 , thinkers seriously started to wonder if "the old ghost of the standard of civilization, exorcised after 1945 by the United Nations, had risen from the grave (Mazower 2012, 396)." In response, ASEAN's team of scholars headed by Surin Pitsuwan stated that the regional organization is "already" equipped with relevant mechanisms and instruments to carry out the R2P (High-Level Advisory Panel on the Responsibility to Protect in Southeast Asia 2014). Given that human security challenges posed by nature and humans continue to confront the region and that East Asian people prefer the holistic approach to address them, the "oriental" way of securing freedom will never cease to exist.

\section{Notes}

1. The paternalist norm of governance prevalent in some Asian countries should be distinguished from the controversial modalities of intervention such as technocratic "libertarian paternalism" in behavioral economics (Thaler and Sunstein 2008) and paternalistic humanitarianism (Barnett 2011).

2. Trilateral collaboration between China, South Korea and Japan in the field of development assistance was gaining momentum by 2011 . Accessed August 26, 2017. https://www.jica.go.jp/english/news/opinion/2012/120702_01.html

3. See the United Nation's Sustainable Development Knowledge Platform. Accessed August 26, 2017. https://sustainabledevelopment.un.org/sdgs

4. Many of the individual chapters of this book discuss this aspect. For a more detailed issue-based study of human security in East Asia, see Hernandez et al. (2018). 
5. As for a mapping of the pros and cons vis-à-vis the human security concept, see various articles in the special section on "What is "Human Security" in Security Dialogue 35(3), 2004. Tadjbakhsh and Chenoy (2007) tried to shift the gravity of the human security discourse to the "South" by capturing its holistic vigor.

6. Note that this is based on how the R2P is commonly perceived (and this perception is reflected in the 2012 UNGA resolution). As a statutory norm, the R2P consists of three pillars: (1) every state has the responsibility to protect its populations, (2) the international community has the responsibility to assist every state in assuming that responsibility, and (3) when a state fails to protect citizens, the internal community should be prepared to take collective action. It is evident that the first two pillars resonate with the idea of human security. For a nuanced review of the entanglements of the two norms of non-intervention and intervention, with a relative commitment to the former, see Doyle (2015).

\section{REFERENCES}

Acharya, Amitav. 2014. Constructing a Security Community in Southeast Asia: ASEAN and the Problem of Regional Order. 3rd ed. London: Routledge.

Adler, Emanuel. 2005. Communitarian International Relations: The Epistemic Foundations of International Relations. London: Routledge.

Anderson, Benedict. 1983. Imagined Communities: Reflections on the Origin and Spread of Nationalism. London: Verso.

Anderson, Mary B. 1999. Do No Harm: How Aid Can Support Peace - or War. Boulder: Lynne Rienner Publishers.

Barnett, Michael. 2011. Empire of Humanity: A History of Humanitarianism. Ithaca: Cornell University Press.

Beck, Ulrich. 1992. Risk Society: Towards a New Modernity. Trans. Mark Ritter. London: Sage.

Caballero-Anthony, Mely, ed. 2016. An Introduction to Non-Traditional Security Studies: A Transnational Approach. Los Angeles: Sage.

Deutsch, Karl W., Sidney A. Burrel, Robert A. Kann, Maurice Lee Jr., Martin Lichterman, Raymond E. Lindgren, Francis L. Loewenheim, and Richard W. Van Wagenen. 1957. Political Community and the North Atlantic Area: International Organization in the Light of Historical Experience. Princeton: Princeton University Press.

Doyle, Michael W. 2015. The Question of Intervention: John Stuart Mill and the Responsibility to Protect. New Haven: Yale University Press.

Fitzgerald, John. 2006. Introduction: The Dignity of Nations. In The Dignity of Nations: Equality, Competition, and Honor in East Asian Nationalism, ed. Sechin Y.S. Chien and John Fitzgerald, 1-22. Hong Kong: Hong Kong University Press. 
Fukuda-Parr, Sakiko, Carlos Lopes, and Khalid Malik, eds. 2002. Capacity for Development: New Solutions to Old Problems. London/New York: Earthscan/ United Nations Development Programme.

Geertz, Clifford. 1980. Negara: The Theatre State in Nineteenth-Century Bali. Princeton: Princeton University Press.

Hernandez, Carolina, Eun Mee Kim, Yoichi Mine, and Ren Xiao, eds. 2018. Human Security and Cross-Border Cooperation in East Asia. New York: Palgrave Macmillan.

High-Level Advisory Panel on the Responsibility to Protect in Southeast Asia (Chaired by Dr. Surin Pitsuwan). 2014. Mainstreaming the Responsibility to Protect in Southeast Asia: Pathway Towards a Caring ASEAN Community. Report of the Advisory Panel Presented at the United Nations, New York, September 9 .

ICISS (International Commission on Intervention and State Sovereignty). 2001. The Responsibility to Protect: Report of the International Commission on Intervention and State Sovereignty. International Development Research Centre (IDRC): Ottawa.

IFRC (International Federation of Red Cross and Red Crescent Societies). 2016. World Disasters Report 2016. Geneva: IFRC.

JICA (Japan International Cooperation Agency). 2008. Capacity Assessment Handbook: Project Management for Realizing Capacity Development. Tokyo: JICA Research Institute.

Mazower, Mark. 2012. Governing the World: The History of an Idea. New York: Penguin Press.

Mine, Yoichi. 2007. Downside Risks and Human Security. In Protecting Human Security in a Post 9/11 World: Critical and Global Insights, ed. Giorgio Shani, Makoto Sato, and Mustapha Kamal Pasha, 64-79. Basingstoke: Palgrave Macmillan.

Paris, Roland. 2001. Human Security: Paradigm Shift or Hot Air? International Security 26 (2): 87-102.

Ruggie, John Gerard. 1996. Winning the Peace: America and World Order in the New Era. New York: Columbia University Press.

Scott, James C. 2009. The Art of Not Being Governed: An Anarchist History of Upland Southeast Asia. New Haven: Yale University Press.

Sen, Amartya. 1981. Poverty and Famines: An Essay on Entitlement and Deprivation. Oxford: Clarendon Press.

- 2014. Birth of a Discourse. In Routledge Handbook of Human Security, ed. Mary Martin and Taylor Owen, 17-27. Abingdon, Oxon: Routledge.

Tadjbakhsh, Shahrbanou, and Anuradha M. Chenoy. 2007. Human Security: Concepts and Implications. Abingdon, Oxon: Routledge.

Thaler, Richard H., and Cass R. Sunstein. 2008. Nudge: Improving Decisions about Health, Wealth, and Happiness. New Haven: Yale University Press. 
UN (United Nations). 2004. A More Secure World: Our Shared Responsibility: Report of the High-Level Panel on Threats, Challenges and Change. New York: United Nations.

UNGA (United Nations General Assembly). 2012. Follow-up to Paragraph 143 on Human Security of the 2005 World Summit Outcome, September 10, A/RES/66/290.

UNHSU (United Nations Human Security Unit). 2009. Human Security in Theory and Practice: Application of the Human Security Concept and the United Nations Trust Fund for Human Security. New York: Human Security Unit, Office for the Coordination of Humanitarian Affairs, United Nations.

UNOCHA-ROAP (United Nations Office for the Coordination of Humanitarian Affairs, Regional Office for Asia and the Pacific). 2013. II. International Humanitarian Architecture. Disaster Response in Asia and the Pacific. Disaster Response in Asia and the Pacific. Thailand: UNOCHA-ROAP.

UNSG (United Nations Secretary General). 2013. Follow-up to General Assembly Resolution 66/290 on Human Security. Report of the Secretary-General, A/68/685, December 23.

Wenger, Etienne. 1998. Communities of Practice: Learning, Meaning, and Identity. Cambridge: Cambridge University Press.

Wittfogel, Karl A. 1957. Oriental Despotism: A Comparative Study of Total Power. New Haven: Yale University Press.

World Bank. 1993. The East Asian Miracle: Economic Growth and Public Policy. New York: Oxford University Press. 